\title{
Glottic Cancer pT4a TNM Finding v6
}

National Cancer Institute

\section{Source}

National Cancer Institute. Glottic Cancer pT 4a TNM Finding v6. NCI Thesaurus. Code C64678.

Glottic cancer with tumor invading through thyroid cartilage and/or invading tissues beyond the larynx (e.g. trachea, soft tissues of neck including deep extrinsic muscle of the tongue, strap muscles, thyroid, or esophagus). (from AJCC 6th Ed.) 